Mesopotamia J. of Agric.

(4) 2005

(ISSN $1815-316 \mathrm{X})$

Vol.(33) No.

\title{
EFFICACY OF ACTIVATED SODIUM BENTONITE TO REDUCE THE TOXICITY OF AFLATOXINS AND T-2 TOXIN IN BROILER CHICKS
}

K.M. Thalij

Food Science and Biotechnology, College of Agric.,Univ. of Tikrit, Tikrit, IRAQ.

\begin{abstract}
This experiment was conducted to determine the ability of activated sodium bentonite(ASB) at a concentration of $0.5 \%$ to reduce the toxicity of aflatoxins (AF) at $2.5 \mathrm{mg}$ or T-2 toxin at $4 \mathrm{mg} / \mathrm{kg}$ of feeds alone or in combination on one-day-old male broiler chicks feed for three weeks. Results indicated the BW gain was reduced significantly $(\mathrm{p}<0.05)$ when feeds containing AF or T2 and AF with T-2 toxin to $26.17,18.88$ and $37.38 \%$ respectively, and become 17.4, 14 and $30.81 \%$ respectively changed from control group when adding ASB. The decreased feed consumption, efficiency feed utilization, the increased relative (liver, kidney, heart, spleen, pancreas, gizzard) proventiculus weights, decreased relative bursal of fabricious, thymus gland weights , increased in the total leucocytes counts, absolute numbers of heterophils, decreased the lymphocyte, monocyte and basophiles were significantly diminished to different degrees by the sorbent in the feed containing AF alone or with T-2 toxin, while the T-2 toxin group was not affected except increased the relative gizzard weight and decreased relative bursal of Fabricious and thymus gland weights and decreased in total leucocytes counts. The adding ASB did not diminish the toxic effects of T-2 toxin on these parameters.
\end{abstract}

\section{INTRODUCTION}

Aflatoxins (AF) are a group of closely related biologically active mycotoxins produced primarily by some strains of Aspergillus flavus and by most strains of A. parasiticus, plus related species A. nomius (Cotty, et al. 1994). The toxicity of AF in young broiler chicks has been well documented (Huff, et al. 1988). Fusarium species are common soil fungi that may frequently contaminate grains that may be used in poultry feed. The mycotoxin called T-2 is a secondary metabolite produced by several species of the genus Fusarium (Cheeke and Shull, 1985) and has shown to causes reductions in weight gain and feed consumption and sever oral lesions in chickens (Huff et al., 1988 ; Kubena et al.,1990 and1994) abnormal behavior (Wyatt et al.,1973) and a coagulopathy (Doerr et al.,1981). Aspergillus and Fusarium may coexist on grains such as corn because of the similar optimum temperature range for maximum production of toxins. The simultaneous feeding of two mycotoxins may cause enhanced toxicity comparing with the toxicity of the individual mycotoxins (Huff, et al.,1988).

Practical methods for detoxifying mycotoxins containing feeds on a large commercial scale in a cost-effective are not currently available. A new approach to this problem has been the dietary addition of inorganic sorbent 
materials, such as hydrated sodium calcium aluminosilicate (HSCAS) or activated sodium bentonite. In recent years, the last adsorbent was reported to be effective in reducing some mycotoxicosis in broiler chicks (Dale and Wyatt, 1995 and Ibrahim et al.,2000). Therefore, the purpose of this study was to investigate the major effects of feeding diets containing AF and T-2 toxin singly or in combination and the effect of ASB in reducing the mycotoxicosis in male broiler chicks to $3 \mathrm{wk}$ of age.

Received 16/08/2005

Mesopotamia J. of Agric. ९९९९९ccepted $23 / 11 / 2005$

(ISSN 1815-316 X)

(4) 2005
Vol.(33) No.

\section{MATERIALS AND METHODS}

One hundred and sixty 1-day-old male broiler chicks(Faobro, an Iragi broiler hybrid) were individually weighed, wing banded and housed in heated battery brooders under continuous fluorescent lighting with feed and water provided ad libitum. Chicks were fed a corn-soyabean meal-based starter diet obtained from a commercial mill; ; it contained $22 \%$ crude protein and $2950 \mathrm{~K}$ $\mathrm{cal} / \mathrm{kg}$ metabolizable energy, without adding antibiotics, coccidiostats, or growth promoters. The experimental design consisted of eight dietary treatments: 1) Control with $0 \mathrm{mg} \mathrm{AF}, 0 \mathrm{mg}$ T-2 toxin, 0\% ASB; 2) $0.05 \%$ ASB; 3) $2.5 \mathrm{mg} \mathrm{AF} / \mathrm{kg}$ of diet; 4) $2.5 \mathrm{mg} \mathrm{AF} / \mathrm{kg}$ of $\operatorname{diet}+0.05 \% \mathrm{ASB}$; 5) $4 \mathrm{mg} \mathrm{T}-2$ toxin $/ \mathrm{kg}$ of diet; 6) $4 \mathrm{mg} \mathrm{T}-2$ toxin $/ \mathrm{kg}$ of diet $+0.05 \% \mathrm{ASB}$; 7) $2.5 \mathrm{mg} \mathrm{AF}+4$ $\mathrm{mg} \mathrm{T}-2$ toxin $/ \mathrm{kg}$ of diet; 8) $2.5 \mathrm{mg} \mathrm{AF}+4 \mathrm{mg} \mathrm{T}-2$ toxin $/ \mathrm{kg}$ of diet $+0.05 \%$ ASB. These were two replicates of ten broilers per dietary treatment and the chicks were maintained on these treatments to $3 \mathrm{wk}$ of age. Aflatoxin was prepared through inoculation of rice by Aspergillus parasiticus NRRL 2999 by methods previously described by Kubena et al. (1990). Fermented rice was autoclaved and ground and the AF content measured by Spectrophotometric analysis ( Nabney and Nesbitt, 1965 ; Wiseman et al.,1967). The total AF content in the rice powder $80 \%$ was AFB1 , 14\% was AFG1, 5\% was AFB2 and $1 \%$ was AFG2. The T-2 toxin was produced by Fusarium sporotrichioides (Laboratory isolate) in cracked corn at $15^{\circ} \mathrm{c}$ by method previously described by Cullen et al. (1982). T-2 toxin was extract and determined under the conditions described by Lawrence, and Scott (1993) and incorporated into the diet by dissolving the toxin in 95\% ethanol and then mixing the appropriate quantities with $1 \mathrm{~kg}$ of the diet. After drying, the dissolved toxin was mixed with the basal diet to produce the treatments containing T-2 toxin. The basal diet was analyzed for mycotoxins and was found to be below detection limits for AF, ochratoxin, zearalenone as established by the methods described by Clement and Phillips (1985). The activated sodium bentonite (ASB) was kindly provided by the state of Vegetable oil and incorporated into the appropriate diets at the level of $0.5 \%$.

The birds were weighed individually, and feed consumption was recorded weekly. At 3 wk of age, 10 broilers (5 chicks from each replicate) from each 
treatment were bled by cardiac puncture for hematological determinations. The total erythrocyte counts were made according to Natt and Herrick (1952). Hemoglobin was determined by the method of Sunderman (1953). While the mean corpuscular volume (MCV), mean corpuscular hemoglobin $(\mathrm{MCH})$, and mean corpuscular volume (MCHC) were calculated (Jain, 1986). The same chicks were then killed by cervical dislocation and the liver, kidney, heart, spleen, pancreas, proventriculus, gizzard, bursa of Fabricius and thymus gland were removed and weighed.

Data were analyzed by the ANOVA analysis, using the general linear model of the Statical Analysis System (SAS Institute, 2001). Significant treatment differences were evaluated using Duncan's multiple-range test (Duncan,1955). All statements of significance are based on the 0.05 level of probability.

\section{RESULTS AND DISCUSSION}

The effects of ASB on performance of chicks fed diets containing AF or T2 toxin are presented in Table 1. Body weight gain, feed consumption, and efficiency of feed utilization were not significantly $(p<0.05)$ influenced by the adsorbent in the absence toxins. When compared with controls, BW gain was reduced during $1 \mathrm{st}, 2 \mathrm{nd}, 3 \mathrm{rd} \mathrm{wk}$
Mesopotamia J. of Agric.
(ISSN $1815-316 \mathrm{X})$
Vol.(33) No.

(4) 2005

and the overall experimental period 21d-old. The reduction in BW gain caused by $2.5 \mathrm{mg}$ AF or $4 \mathrm{mg} \mathrm{T}-2 / \mathrm{kg}$ of diet singly or in combination was diminished by the addition of $0.5 \%$ ASB. Feed consumption and the efficiency of feed utilization were significantly $(\mathrm{p}<0.05)$ reduced in all toxin treated groups and the addition of ASB did not offer total protection as evidenced by this parameters that were intermediate between those of control and toxins groups.

Table 1: The effects of activated sodium bentonite on performance of male chicks fed diets containing $2.5 \mathrm{mg}$ AF or $4 \mathrm{mg}$ T-2 toxin/ $/ \mathrm{kg}$ diet, singly or in combination.

\begin{tabular}{|c|c|c|c|c|c|c|c|c|c|}
\hline $\mathrm{AF}^{*}$ & $\mathrm{~T}-2$ & ASB & \multicolumn{4}{|c|}{ Body weight gain(g/bird/wk) } & \multirow{2}{*}{$\begin{array}{l}\text { Change } \\
\text { from } \\
\text { control\% }\end{array}$} & \multirow{2}{*}{$\begin{array}{c}\text { Total feed } \\
\text { intake(g/bird/ } \\
\text { 3wks) }\end{array}$} & \multirow[t]{2}{*}{ F.C.R. ${ }^{* *}(\mathrm{~g}: \mathrm{g})$} \\
\hline $\mathrm{mg}$ & $\mathrm{kg}$ & $\%$ & $1-7$ & $8-14$ & $15-21$ & $1-21$ & & & \\
\hline 0 & 0 & 0 & $84.0^{\mathrm{a}} \pm 0 . .96$ & $164.6^{\mathrm{a}} \pm 2.44$ & $209.1^{\mathrm{a}} \pm 2.65$ & $458^{\mathrm{ab}} \pm 1.26$ & - & $637^{\mathrm{b}} \pm 4.83$ & $1.39^{\mathrm{f}} \pm 0.004$ \\
\hline 0 & 0 & 0.5 & $82.0^{\mathrm{a}} \pm 1.30$ & $165.9^{\mathrm{a}} \pm 1.45$ & $212.3^{\mathrm{a}} \pm 1.31$ & $461^{\mathrm{a}} \pm 1.85$ & -0.66 & $652^{\mathrm{a}} \pm 4.53$ & $1.42^{\mathrm{f}} \pm 0.02$ \\
\hline 2.5 & 0 & 0 & $62.9^{\mathrm{e}} \pm 2.01$ & $115.9^{\mathrm{c}} \pm 3.05$ & $159.1^{\mathrm{e}} \pm 2.55$ & $338^{\mathrm{f}} \pm 1.37$ & -26.17 & $598^{\mathrm{e}} \pm 0.77$ & $1.77^{\mathrm{c}} \pm 0.008$ \\
\hline 2.5 & 0 & 0.5 & $77.6^{\mathrm{b}} \pm 0.74$ & $129.2^{\mathrm{d}} \pm 0.88$ & $171.2^{\mathrm{d}} \pm 1.46$ & $378^{\mathrm{d}} \pm 1.29$ & -17.41 & $633^{\mathrm{c}} \pm 1.29$ & $1.68^{\mathrm{d}} \pm 0.007$ \\
\hline 0 & 4.0 & 0 & $68.3^{\mathrm{d}} \pm 1.25$ & $117.1^{\mathrm{c}} \pm 1.90$ & $185.9^{\mathrm{c}} \pm 1.05$ & $371^{\mathrm{e}} \pm 1.03$ & -18.88 & $609^{\mathrm{d}} \pm 1.02$ & $1.64^{\mathrm{e}} \pm 0.004$ \\
\hline 0 & 4.0 & 0.5 & $73.7^{\mathrm{c}} \pm 0.98$ & $126.6^{\mathrm{b}} \pm 1.48$ & $193.3^{\mathrm{b}} \pm 1.15$ & $393^{f} \pm 0.69$ & -14.00 & $616^{c} \pm 3.04$ & $1.56^{\mathrm{e}} \pm 0.003$ \\
\hline 2.5 & 4.0 & 0 & $61.5^{\mathrm{e}} \pm 1.54$ & $84.2^{\mathrm{e}} \pm 1.39$ & $140.9^{\mathrm{g}} \pm 1.84$ & $287^{\mathrm{h}} \pm 1.39$ & -73.38 & $568^{\mathrm{g}} \pm 1.36$ & $1.98^{\mathrm{a}} \pm 0.06$ \\
\hline 2.5 & 4.0 & 0.5 & $71.9^{c} \pm 1.32$ & $96.9^{f} \pm 1.65$ & $147.9^{\mathrm{f}} \pm 1.66$ & $\begin{array}{c}\square 317^{\mathrm{g}} \pm 1.0 \\
7\end{array}$ & -30.81 & $\square 574^{\mathrm{f}} \pm 1.33$ & $\square 1.81^{\mathrm{b}} \pm 0.04$ \\
\hline
\end{tabular}

a-h : Means in each column bearing different letters differ significantly $(\mathrm{p}<0.05)$.

$* \mathrm{AF}=$ Aflatoxins. $* *$ F.C.R. $=$ Feed conversion ratio(g feed/g gain).

Data presented in Table 2 show the effects of treatments on the relative organ weights (gram per $100 \mathrm{~g}$ of BW). When compared with control group, relative liver, kidney, heart, spleen, pancreas, gizzard and proventriculus 
weights were increased significantly $(\mathrm{p}<0.05)$ and while the relative weights of bursa of Fabricius and thymus gland were decreased when chicks fed diets containing AF alone or in combination with $\mathrm{T}-2$ toxin. Feeding $\mathrm{T}-2$ toxin caused an increase in the relative weight of the gizzard only but the other relative weights of organs were not changed. Adding ASB to the diet containing AF alone or in combination with $\mathrm{T}-2$ was diminished the effects of the toxins on the relative weights of all organs. When ASB was added to the diet containing T-2 alone did not change the relative weight of gizzard.

Table 3 presents the effects of treatments on blood parameters of growing chicks. Hemoglobin (HB), red blood cell counts (RBC), packed cell volume $(\mathrm{PCV})$, were significantly $(\mathrm{p}<0.05)$ depressed in $\mathrm{AF}$ or $\mathrm{T}-2$ toxins groups individually or in combination compared to the control group.

Feeding AF alone or combination with $\mathrm{T}-2$ toxin in the diet caused significant $(\mathrm{p}<0.05)$ decrease in the mean corpuscular volume $(\mathrm{MCV})$, mean corpuscular hemoglobin ( $\mathrm{MCH})$, and mean corpuscular hemoglobin concentration (MCHC), whereas $\mathrm{MCV}, \mathrm{MCH}$, and $\mathrm{MCHC}$, were unchanged by dietary T-2 toxin alone. The addition of ASB at $0.5 \%$ did not offer total protection as evidenced by blood parameters that were intermediate between these of controls and AF or T-2 toxin singly or in combination.

Data in Tables 4 and 5 show the effects of feeding diets contaning AF or T2 singly or in combination with or without ASB on total leucocytes count, absolute number of leucocytes, differential counts of leucocytes and the heterophils:lymphocytes ratio in chicks at the age of three weeks. The results indicated that the presence of $\mathrm{AF}$ alone or in combination with $\mathrm{T}-2$ toxin in the diet caused a significant $(\mathrm{p}<0.05)$ increase in the total leukocyte count, whereas feeding the T-2 toxin alone was significantly decreased in

Mesopotamia J. of Agric.

(ISSN $1815-316 \quad \mathrm{X})$

Vol.(33)

No. (4) 2005

total leukocyte counts, when compared with control group.

Table 2: The effects of activated sodium bentonite on relative organ weights of male chicks fed diets containing $2.5 \mathrm{mg}$ AF or $4 \mathrm{mg}$ T-2 toxin/ $\mathrm{kg}$ diet, singly or in combination.

\begin{tabular}{|c|c|c|c|c|c|c|c|c|c|c|c|}
\hline $\mathrm{AF}^{*}$ & $\mathrm{~T}-2$ & ASB & \multicolumn{9}{|c|}{$\mathrm{gm} / 100 \mathrm{~g}$ of body weights } \\
\hline \multicolumn{2}{|c|}{$\mathrm{Mg} / \mathrm{kg}$} & $\%$ & Liver & Kidney & Heart & Spleen & Pancreas & Gizzard & $\begin{array}{c}\text { Provent- } \\
\text { riculus }\end{array}$ & $\begin{array}{c}\text { Bursa of } \\
\text { Fabricius }\end{array}$ & $\begin{array}{c}\text { Thymus } \\
\text { gland }\end{array}$ \\
\hline 0 & 0 & 0 & $\begin{array}{l}2.82^{\mathrm{e}} \\
\pm 0.07\end{array}$ & $\begin{array}{l}0.71^{\mathrm{c}} \\
\pm 0.01\end{array}$ & $\begin{array}{l}0.53^{\mathrm{d}} \\
\pm 0.01\end{array}$ & $\begin{array}{l}0.10^{\mathrm{c}} \\
\pm 0.01\end{array}$ & $\begin{array}{l}0.35^{\mathrm{c}} \\
\pm 0.01\end{array}$ & $\begin{array}{l}2.65^{\mathrm{f}} \\
\pm 0.02\end{array}$ & $\begin{array}{l}0.71^{\mathrm{d}} \\
\pm 0.01\end{array}$ & $\begin{array}{l}0.39^{\mathrm{a}} \\
\pm 0.01\end{array}$ & $\begin{array}{l}0.42^{\mathrm{a}} \\
\pm 0.01\end{array}$ \\
\hline 0 & 0 & 0.5 & $\begin{array}{l}2.87^{\mathrm{e}} \\
\pm 0.05\end{array}$ & $\begin{array}{l}0.72^{\mathrm{c}} \\
\pm 0.01\end{array}$ & $\begin{array}{l}0.54^{\mathrm{d}} \\
\pm 0.01\end{array}$ & $\begin{array}{l}0.10^{\mathrm{c}} \\
\pm 0.01\end{array}$ & $\begin{array}{l}0.35^{\mathrm{c}} \\
\pm 0.04\end{array}$ & $\begin{array}{l}2.67^{\mathrm{f}} \\
\pm 0.01\end{array}$ & $\begin{array}{l}0.72^{\mathrm{d}} \\
\pm 0.01\end{array}$ & $\begin{array}{l}0.39^{\mathrm{a}} \\
\pm 0.01\end{array}$ & $\begin{array}{l}0.41^{\mathrm{a}} \\
\pm 0.01\end{array}$ \\
\hline 2.5 & 0 & 0 & $\begin{array}{l}4.15^{\mathrm{b}} \\
\pm 0.08\end{array}$ & $\begin{array}{l}0.81^{\mathrm{b}} \\
\pm 0.01\end{array}$ & $\begin{array}{l}0.80^{\mathrm{a}} \\
\pm 0.01\end{array}$ & $\begin{array}{l}0.19^{\mathrm{a}} \\
\pm 0.01\end{array}$ & $\begin{array}{l}0.49^{\mathrm{a}} \\
\pm 0.01\end{array}$ & $\begin{array}{l}2.83^{\mathrm{a}} \\
\pm 0.01\end{array}$ & $\begin{array}{l}0.83^{\text {ab }} \\
\pm 0.01\end{array}$ & $\begin{array}{l}0.27^{\mathrm{d}} \\
\pm 0.01\end{array}$ & $\begin{array}{l}0.19^{\mathrm{e}} \\
\pm 0.01\end{array}$ \\
\hline 2.5 & 0 & 0.5 & $\begin{array}{l}3.60^{\mathrm{d}} \\
\pm 0.08\end{array}$ & $\begin{array}{l}0.77^{\mathrm{b}} \\
\pm 0.01\end{array}$ & $\begin{array}{c}0.77^{\mathrm{b}} \\
\pm 0.01\end{array}$ & $\begin{array}{l}0.12^{\mathrm{c}} \\
\pm 0.01\end{array}$ & $\begin{array}{l}0.40^{\mathrm{b}} \\
\pm 0.01\end{array}$ & $\begin{array}{l}2.75^{\mathrm{cd}} \\
\pm 0.01\end{array}$ & $\begin{array}{l}0.78^{\mathrm{c}} \\
\pm 0.01\end{array}$ & $\begin{array}{l}0.34^{\mathrm{b}} \\
\pm 0.01\end{array}$ & $\begin{array}{l}0.31^{\mathrm{c}} \\
\pm 0.01\end{array}$ \\
\hline 0 & 4.0 & 0 & $\begin{array}{l}2.90^{\mathrm{e}} \\
\pm 0.06\end{array}$ & $\begin{array}{l}0.69^{\mathrm{c}} \\
\pm 0.02\end{array}$ & $\begin{array}{l}0.52^{\mathrm{c}} \\
\pm 0.01\end{array}$ & $\begin{array}{l}0.13^{\mathrm{c}} \\
\pm 0.01\end{array}$ & $\begin{array}{l}0.37^{\mathrm{bc}} \\
\pm 0.01\end{array}$ & $\begin{array}{l}2.79^{\mathrm{b}} \\
\pm 0.01\end{array}$ & $\begin{array}{l}0.73^{\mathrm{d}} \\
\pm 0.01\end{array}$ & $\begin{array}{l}0.30^{\mathrm{c}} \\
\pm 0.01\end{array}$ & $\begin{array}{l}0.31^{\mathrm{c}} \\
\pm 0.01\end{array}$ \\
\hline 0 & 4.0 & 0.5 & $\begin{array}{l}2.89^{\mathrm{e}} \\
\pm 0.02\end{array}$ & $\begin{array}{l}0.70^{\mathrm{c}} \\
\pm 0.01\end{array}$ & $\begin{array}{c}0.50^{\mathrm{c}} \\
\pm 0.01\end{array}$ & $\begin{array}{l}0.11^{\mathrm{c}} \\
\pm 0.01\end{array}$ & $\begin{array}{l}0.36^{\mathrm{bc}} \\
\pm 0.01\end{array}$ & $\begin{array}{l}2.77^{b} \\
\pm^{c} 0.01\end{array}$ & $\begin{array}{l}0.70^{\mathrm{d}} \\
\pm 0.01\end{array}$ & $\begin{array}{l}0.34^{\mathrm{b}} \\
\pm 0.01\end{array}$ & $\begin{array}{l}0.36^{\mathrm{b}} \\
\pm 0.01\end{array}$ \\
\hline 2.5 & 4.0 & 0 & $4.62^{\mathrm{a}}$ & $0.84^{\mathrm{a}}$ & $0.79^{\text {abv }}$ & $0.20^{\mathrm{a}}$ & $0.50^{\mathrm{a}}$ & $2.86^{\mathrm{a}}$ & $0.85^{\mathrm{a}}$ & $0.25^{\mathrm{d}}$ & $0.20^{\mathrm{de}}$ \\
\hline
\end{tabular}




\begin{tabular}{|l|c|c|c|c|c|c|c|c|c|c|c|}
\hline & & & \pm 0.01 & \pm 0.01 & \pm 0.01 & \pm 0.01 & \pm 0.01 & \pm 0.01 & \pm 0.01 & \pm 0.01 & \pm 0.01 \\
\hline \multirow{2}{*}{2.5} & \multirow{2}{*}{4.0} & \multirow{2}{*}{0.5} & $3.94^{\mathrm{c}}$ & $0.78^{\mathrm{b}}$ & $0.78^{\mathrm{ab}}$ & $0.17^{\mathrm{b}}$ & $0.49^{\mathrm{a}}$ & $2.73^{\mathrm{de}}$ & $0.81^{\mathrm{b}}$ & $0.27^{\mathrm{d}}$ & $0.22^{\mathrm{d}}$ \\
& & & \pm 0.05 & \pm 0.01 & \pm 0.01 & \pm 0.01 & \pm 0.01 & \pm 0.02 & \pm 0.01 & \pm 0.01 & \pm 0.01 \\
\hline
\end{tabular}

a-f : Means in each column bearing different letters differ significantly $(\mathrm{p}<0.05)$.

$* \mathrm{AF}=$ Aflatoxins.

Table 3: The effects of activated sodium bentonite on haematological values of male chicks fed diets containing $2.5 \mathrm{mg}$ AF or $4 \mathrm{mg}$ T-2 toxin/kg diet, singly or in combination.

\begin{tabular}{|c|c|c|c|c|c|c|c|c|}
\hline $\mathrm{AF}^{*}$ & $\mathrm{~T}-2$ & ASB & $\mathrm{Hb}-$ & $\mathrm{RBC}$ & $\mathrm{PCV}$ & $\mathrm{MCV}$ & $\mathrm{MCH}$ & $\mathrm{MCHC}$ \\
\hline \multicolumn{2}{|c|}{$\mathrm{mg} / \mathrm{kg}$} & $\%$ & $\mathrm{~g} / 100 \mathrm{ml}$ & $\left(\mathrm{x} 10^{6} / \mathrm{mm}^{3}\right)$ & $\%$ & $\left(\mu \mathrm{m}^{3}\right)$ & $\mathrm{Pg}$ & $\mathrm{g} / \mathrm{dl}$ \\
\hline 0 & 0 & 0 & $8.23^{\mathrm{a}} \pm 0.13$ & $2.69^{\mathrm{a}} 0.01$ & $45.3^{\mathrm{a}} 1.00$ & $168^{\mathrm{a}} \pm 3.25$ & $30.6^{\mathrm{a}} \pm 0.56$ & $18.2^{\mathrm{ab}} \pm 0.53$ \\
\hline 0 & 0 & 0.5 & $8.05^{\mathrm{ab}} \pm 0.11$ & $2.64^{\mathrm{a}} \pm 0.01$ & $44.4^{\mathrm{ab}} \pm 0.65$ & $168^{\mathrm{a}} \pm 2.74$ & $30.5^{\mathrm{a}} \pm 0.46$ & $18.1^{\mathrm{b}} \pm 0.44$ \\
\hline 2.5 & 0 & 0 & $5.24^{\mathrm{d}} \pm 0.12$ & $2.22^{\mathrm{d}} \pm 0.01$ & $27.4^{\mathrm{d}} \pm 0.75$ & $123^{\mathrm{b}} \pm 3.47$ & $23.6^{\mathrm{b}} \pm 0.58$ & $19.1^{\mathrm{ab}} \pm 0.59$ \\
\hline 2.5 & 0 & 0.5 & $5.54^{\mathrm{de}} \pm 0.07$ & $2.3^{\mathrm{c}} \pm 0.01$ & $27.5^{\mathrm{d}} \pm 0.54$ & $119^{\mathrm{b}} \pm 2.45$ & $24.0^{\mathrm{b}} \pm 0.32$ & $21.1^{\mathrm{a}} \pm 0.39$ \\
\hline 0 & 4.0 & 0 & $7.83^{\mathrm{bc}} \pm 0.09$ & $2.59^{\mathrm{b}} \pm 0.01$ & $41.9^{\mathrm{c}} \pm 0.62$ & $162^{\mathrm{a}} \pm 2.12$ & $30.2^{\mathrm{a}} \pm 0.25$ & $18.7^{\mathrm{ab}} \pm 0.24$ \\
\hline 0 & 4.0 & 0.5 & $7.70^{\mathrm{c}} \pm 0.07$ & $2.62^{\mathrm{b}} \pm 0.01$ & $43.2^{\mathrm{bc}} \pm 0.51$ & $165^{\mathrm{a}} \pm 2.15$ & $29.4^{\mathrm{a}} \pm 0.33$ & $17.8^{\mathrm{bc}} \pm 0.24$ \\
\hline 2.5 & 4.0 & 0 & $4.39^{\mathrm{f}} \pm 0.12$ & $2.23^{\mathrm{d}} \pm 0.01$ & $24.5^{\mathrm{e}} \pm 0.81$ & $110^{\mathrm{c}} \pm 3.34$ & $19.7^{\mathrm{c}} \pm 0.55$ & $17.9^{\mathrm{b}} \pm 0.62$ \\
\hline 2.5 & 4.0 & 0.5 & $4.90^{\mathrm{e}} \pm 0.08$ & $2.37^{\mathrm{c}} \pm 0.06$ & $25.1^{\mathrm{e}} \pm 0.53$ & $106^{\mathrm{c}} \pm 3.65$ & $20.7^{\mathrm{c}} \pm 0.56$ & $19.5^{\mathrm{ab}} \pm 0.49$ \\
\hline
\end{tabular}

a-f : Means in each column bearing different letters differ significantly $(\mathrm{p}<0.05)$.

$* \mathrm{AF}=$ Aflatoxins. $\cdot \mathrm{Hb}=$ hemoglobin. $\cdot \mathrm{RBC}=\mathrm{Red}$ blood cells. $\cdot \mathrm{PCV}=$ mean corpuscular

volume. $\quad-\mathrm{MCH}=$ mean corpuscular hemoglobin. $\quad \cdot \mathrm{MCHC}=$ mean corpuscular hemoglobin

concentration.

The absolute number of lymphocytes, monocytes and basophils were reduced and heterophils was increased in chicks fed AF or T-2 singly or in combination. Feeding T-2 alone caused a significant $(\mathrm{p}<0.05)$ decrease in the absolute number of esonophils, while feeding AF alone or in combination with T-2 toxin had no effect on absolute number of esonophils. Heterophils:Lymphocytes ratio in chicks fed diet containing AF or T-2 toxin individually or in combination was significantly higher than those in birds in control group. However, when examining the results concerning the differential counts,it was indicated that the percentage of heterophils was significantly higher, and the percentage of lymphocytes, monocytes, basophils and eosinophils were significantly lower in chicks fed diet containing AF or T-2 singly or in combination, when compared with those of chicks in control group. Although the

Mesopotamia J. of Agric.

(ISSN 1815-316 X)

$$
\text { No. (4) } 2005
$$

Vol.(33)

addition of ASB alone caused a significant increase $(p<0.05)$ in the total leucoctes count when compared with control group. Furthermore, the total leucocyte count, and the absolute numbers of heterophils, monocytes, lymphocytes, basiophils, and eosinophils of chicks fed the diet containing AF or T-2 toxin singly or in combination when amended with ASB did not offer total protection, that were intermediate between those of control and toxins treatments.

Aflatoxins and T-2 toxin are important to the poultry industry because of their toxicity and occurrence in feedstuffs (Kubena, et al., 1990). Reduced body 
weight gain, depreessed feed consumption and efficiency of feed utilization, were the most prevalent symptoms in poultry as a result of feeding AF at rate of $2.5 \mathrm{mg}$ or $4 \mathrm{mg} \mathrm{T}-2$ toxin $/ \mathrm{kg}$ of diet singly or in combination. These symptoms were reported by many investigators (Huff, et al.,1986 ; Kubena, et al., 1998). In the present study, the addition of AF or T-2 toxin to the diet significantly decreased $\mathrm{BW}$ gain at 26.17 , and $18.88 \%$, respectively, in growing chicks. Feeding AF plus T-2 in combination caused a larger reduction in body weight gain than did the feeding of either of the toxins alone $(37.38 \%)$. Whereas, the addition of $0.5 \%$ of ASB to the diets contaminated with AF or T2 toxin singly or in combination resulted in a significant improvement in BW gain which were lower in the percentage of 17.41, 14.0, and 30.81\%, respectively, when compared with that of chicks fed the either of the toxins alone or in combination. ASB supplementation to the mycotoxins contaminated diets did improved feed consumption as well as feed conversion ratio compared with those of mycotoxins treatments. The decreased BW gain and efficiency feed utilization of young chicks are most likely associated with inhibition of protein synthesis by either of the toxin (Kubena, et al., 1994 and 1995a,b). The liver was considered the target organ for $\mathrm{AF}$ in poultry,the relative liver weights as well as relative kidney, heart, spleen, pancreas, gizzard, and proventriculus weights increased in chicks consuming the diets containing AF alone; whereas relative bursa of Fabricius and thymus gland weights decreased. The same responses were observed for the AF plus T-2 treatment. The addition of ASB to the diet containing AF alone or in combination with $\mathrm{T}-2$ toxin counteracted the negative effect of the toxins on relative organs weight. These finding agree with previous results on the protective effects of ASB on relative organs weights of young chicks (Dale and Wyatt, 1995 and Kubena et al., 1990 and 1994).

Table 4: The effects of activated sodium bentonite on the absolute number of leucocytes and the heterophils:lymphocytes ratio of male chicks fed diets containing $2.5 \mathrm{mg} \mathrm{AF}$ or $4 \mathrm{mg} \mathrm{T}-2$ toxin/kg diet, singly or in combination.

\begin{tabular}{|c|c|c|c|c|c|c|c|c|}
\hline $\mathrm{AF}^{*}$ & $\mathrm{~T}-2$ & ASB & Heterophils & Monocytes & Lymphocytes & Eosinophils & Basophils & \multirow[t]{2}{*}{ H:L ratio } \\
\hline \multicolumn{2}{|c|}{$\mathrm{mg} / \mathrm{kg}$} & $\%$ & \multicolumn{5}{|c|}{$\left(10^{3} / \mathrm{mm}^{3}\right)$} & \\
\hline 0 & 0 & 0 & $6.56^{\mathrm{d}} \pm 0.07$ & $1.72^{\mathrm{a}} \pm 0.07$ & $14.54^{\mathrm{a}} \pm 0.18$ & $0.20^{\mathrm{a}} \pm 0.04$ & $1.66^{\mathrm{a}} \pm 0.05$ & $0.45^{\mathrm{d}} \pm 0.05$ \\
\hline 0 & 0 & 0.5 & $7.66^{\mathrm{d}} \pm 0.08$ & $1.79^{\mathrm{a}} \pm 0.08$ & $14.73^{\mathrm{a}} \pm 0.35$ & $0.21^{\mathrm{a}} \pm 0.03$ & $1.60^{\mathrm{a}} \pm 0.02$ & $0.52^{\mathrm{d}} \pm 0.02$ \\
\hline 2.5 & 0 & 0 & $21.75^{\mathrm{a}} \pm 0.06$ & $0.57^{\mathrm{f}} \pm 0.12$ & $9.14^{\mathrm{bc}} \pm 0.21$ & $0.18^{\mathrm{ab}} \pm 0.03$ & $1.50^{\mathrm{b}} \pm 0.11$ & $2.38^{\mathrm{a}} \pm 0.04$ \\
\hline 2.5 & 0 & 0.5 & $17.80^{\mathrm{b}} \pm 0.09$ & $0.74^{\mathrm{d}} \pm 0.06$ & $9.76^{\mathrm{b}} \pm 0.29$ & $0.22^{\mathrm{a}} \pm 0.03$ & $1.51^{\mathrm{b}} \pm 0.09$ & $1.82^{\mathrm{b}} \pm 0.09$ \\
\hline 0 & 4.0 & 0 & $13.29^{c} \pm 0.13$ & $0.64^{\mathrm{e}} \pm 0.14$ & $7.82^{\mathrm{d}} \pm 0.14$ & $0.15^{\mathrm{c}} \pm 0.05$ & $0.87^{\mathrm{e}} \pm 0.04$ & $1.70^{\mathrm{c}} \pm 0.06$ \\
\hline 0 & 4.0 & 0.5 & $13.45^{\mathrm{c}} \pm 0.09$ & $0.72^{\mathrm{d}} \pm 0.04$ & $8.53^{\mathrm{c}} \pm 0.31$ & $0.16^{\mathrm{c}} \pm 0.04$ & $1.18^{\mathrm{d}} \pm 0.02$ & $1.58^{\mathrm{cd}} \pm 0.04$ \\
\hline 2.5 & 4.0 & 0 & $21.88^{\mathrm{a}} \pm 0.06$ & $0.86^{\mathrm{c}} \pm 0.07$ & $8.50^{\mathrm{c}} \pm 0.33$ & $0.18^{\mathrm{ab}} \pm 0.04$ & $1.17^{\mathrm{d}} \pm 0.02$ & $2.57^{\mathrm{a}} \pm 0.09$ \\
\hline 2.5 & 4.0 & 0.5 & $17.37^{\mathrm{b}} \pm 0.05$ & $0.93^{\mathrm{b}} \pm 0.08$ & $9.16^{\mathrm{bc}} \pm 0.34$ & $0.18^{\mathrm{ab}} \pm 0.04$ & $1.40^{\mathrm{c}} \pm 0.08$ & $1.90^{\mathrm{b}} \pm 0.07$ \\
\hline
\end{tabular}

Mesopotamia J. of Agric.

(ISSN 1815-316 X)

Vol.(33) No.

(4) 2005 
Table 5: The effects of activated sodium bentonite (ASB) on total and differential leucocyte counts of male chicks fed diets containing $2.5 \mathrm{mg}$ AF or $4 \mathrm{mg}$ T-2 toxin/kg diet, singly or in combination.

\begin{tabular}{|c|c|c|c|c|c|c|c|c|}
\hline $\mathrm{AF}^{*}$ & $\mathrm{~T}-2$ & ASB & LC. & Heterophils & Monocytes & Lymphocytes & Eosinophils & Basophils \\
\hline \multicolumn{2}{|c|}{$\mathrm{Mg} / \mathrm{kg}$} & $\%$ & $\left(10^{6} / \mathrm{mm}^{3}\right)$ & \multicolumn{5}{|c|}{$\%$} \\
\hline 0 & 0 & 0 & $24.69^{\mathrm{e}} \pm 0.17$ & $26.58^{\mathrm{f}} \pm 0.43$ & $6.97^{\mathrm{a}} \pm 0.08$ & $58.91^{\mathrm{a}} \pm 0.41$ & $0.80^{\mathrm{a}} \mathrm{v} 0.03$ & $6.74^{\mathrm{a}} \pm 0.08$ \\
\hline 0 & 0 & 0.5 & $25.99^{d} \pm 0.18$ & $29.48^{\mathrm{e}} \pm 0.36$ & $6.89^{\mathrm{a}} \pm 0.06$ & $56.68^{\mathrm{b}} \pm 0.33$ & $0.80^{\mathrm{a}} \pm 0.03$ & $6.15^{\mathrm{a}} \pm 0.07$ \\
\hline 2.5 & 0 & 0 & $33.14^{\mathrm{a}} \pm 0.34$ & $65.64^{b} \pm 0.18$ & $1.71^{\mathrm{f}} \pm 0.05$ & $27.58^{\mathrm{g}} \pm 0.19$ & $0.55^{\mathrm{d}} \pm 0.03$ & $4.52^{\mathrm{b}} \pm 0.06$ \\
\hline 2.5 & 0 & 0.5 & $30.02^{b} \pm 0.21$ & $59.28^{\mathrm{c}} \pm 0.38$ & $2.46^{\mathrm{e}} \pm 0.09$ & $32.50^{\mathrm{e}} \pm 0.32$ & $0.74^{\mathrm{ab}} \pm 0.02$ & $5.02^{\mathrm{b}} \pm 0.07$ \\
\hline 0 & 4.0 & 0 & $22.60^{\mathrm{f}} \pm 0.26$ & $58.80^{\mathrm{c}} \pm 0.43$ & $2.85^{\mathrm{cd}} \pm 0.13$ & $34.59^{d} \pm 0.30$ & $0.65^{c} \pm 0.04$ & $3.83^{c} \pm 0.26$ \\
\hline 0 & 4.0 & 0.5 & $24.04^{\mathrm{e}} \pm 0.09$ & $55.94^{\mathrm{d}} \pm 0.33$ & $3.00^{\mathrm{bc}} \pm 0.08$ & $35.47^{\mathrm{c}} \pm 0.34$ & $0.67^{\mathrm{bc}} \pm 0.03$ & $4.92^{\mathrm{b}} \pm 0.43$ \\
\hline 2.5 & 4.0 & 0 & $32.59^{\mathrm{a}} \pm 0.34$ & $67.15^{\mathrm{a}} \pm 0.35$ & $2.64{ }^{\mathrm{de}} \pm 0.09$ & $26.07^{\mathrm{b}} \mathrm{v} 0.02$ & $0.54^{\mathrm{d}} \pm 0.03$ & $3.60^{c} \pm 0.26$ \\
\hline 2.5 & 4.0 & 0.5 & $29.03^{c} \pm 0.33$ & $59.82^{\mathrm{c}} \pm 0.23$ & $3.20^{\mathrm{b}} \pm 0.06$ & $31.55^{\mathrm{f}} \pm 0.28$ & $0.62^{\mathrm{cd}} \pm 0.02$ & $4.81^{\mathrm{b}} \pm 0.18$ \\
\hline
\end{tabular}

a-f : Means in each column bearing different letters differ significantly $(\mathrm{p}<0.05)$.

$* \mathrm{AF}=$ Aflatoxins. $\cdot \mathrm{LC}=$ Total leucocytoses counts.

The increased relative weights of the liver by dietary AF alone or in combination with T-2 toxin might be associated with declaration in lipid metabolism, primarily as a result of impaired lipid transport as suggested by Kubena et al. (1994). The increased relative weights of kidney is probably associated with slight renal damage (Kubena et al., 1995).The increased relative weight of the proventriculus and gizzard reported herein agree with the reports of Kubena et al.(1995 a,b) and likely can be attributed to the overall irritative properties of the mycotoxins, typically described as focally reddened mucosa (Hoerr et al., 1982). The significant effect of AF alone or plus T-2 toxin in decreasing the relative bursa of fabricius and thymus gland weights observed in the present study is of important interest as it may explain the depression of immunity of chicks, since these two organs were considered one of the most important defense lines in birds (Kubena et al., 1990 and Edrington et al., 1997).

The haematological values of Wintrope erythrocyte indicies (MCV,MCH, and $\mathrm{MCHC}$ ) were valuable tools to clear the adverse erythropoietic effects of feeding AF alone or plus T-2 toxin to growing chicks, through the induction of haemolytic anemia, which was also reported by other investigators (Huff et al., 1988 and Kubena et al., 1990). In addition to the previously mentioned positive ameliorating effects of ASB, it was also effective in alleviating toxin negative effects on haemoglobin and haematocrit. These results indicate that AF and T-2 in combination may be more toxic than the individual mycotoxins. These finding clearly demonstrate that, in broiler chicks, ASB significantly diminished some of the toxic effects of AF when present singly or in combination with $\mathrm{T}-2$. The protection against the negative effects of the AF combination with T-2 was not as great for many parameters as would be predicted, based on the protection against AF alone. The protective effect of ASB observed in the present study

confirm the finding of Kubena et al. (1990), Araba and Wyatt (1991) and Dale and Wyatt (1995). In that perhaps there is sufficient unbound AF remaining to interact synergistically with T-2 toxin causing toxic effect than would be predicted. ASB could act a sequestering agent against AF in feeds through its 
adsorption as suggested by Phillips et al.(1988), and therefore reducing the AF bioavailability in the gastrointestinal tract as shown by Davidson et al. (1987).

كفاءة بنتونايت الصوديوم المنشط في خفض سمية كل من سموم الأفلا وسم T-2 في الافراخ النامية

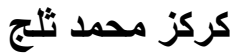

قسم علوم الأغذية و التقانات الإحيائية، كلية الزر اعة، جامعة تكريت، تكريت، العراق.

\section{الخلاصة}

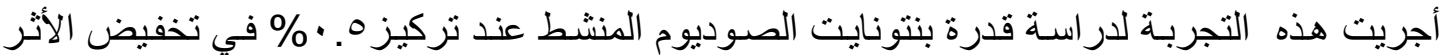

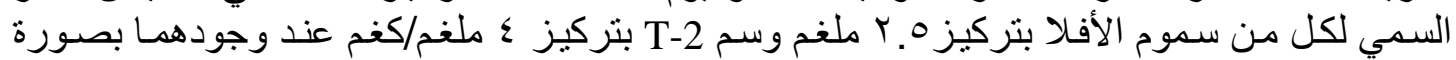

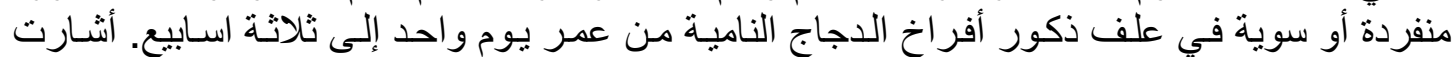

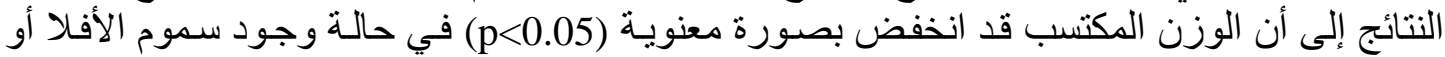

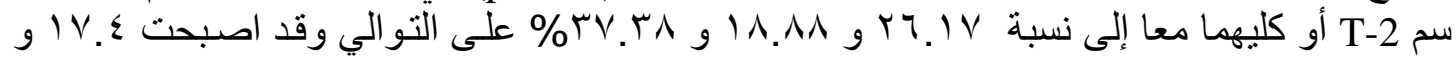

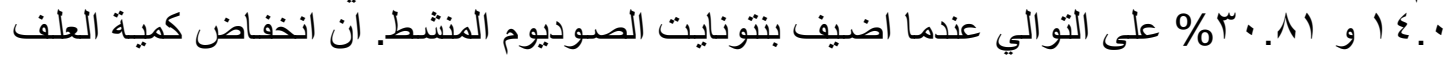

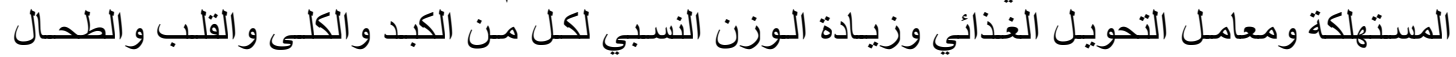

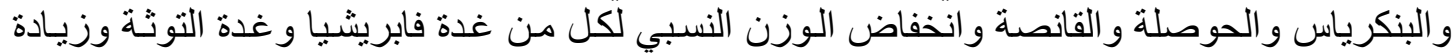

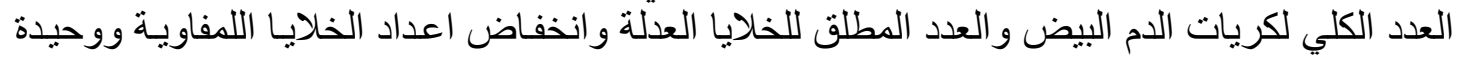

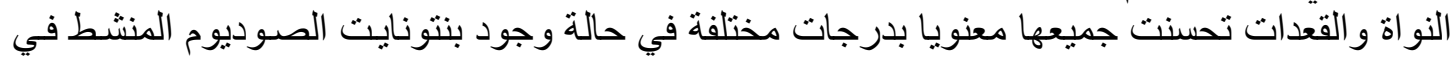

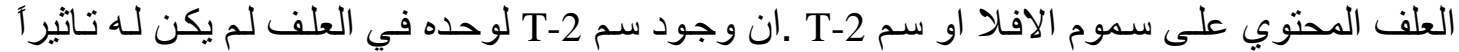

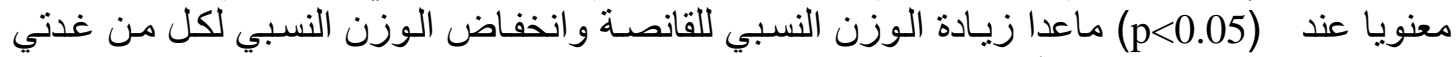

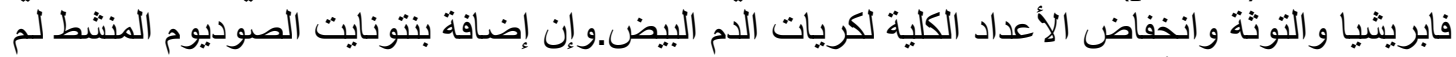
يحسن معنوياً من التأثثر السمي لسم T-2 في الأنغاد المعايير المقاسة.

\section{REFERENCES}

Araba, M.,and R.D. Wyatt (1991). Effects of sodium bentonite hydrated aluminosilicate (Novasil) and ethical on aflatoxicosis in broiler chickens. Poultry Sci. 70 (Suppl. 1): 6(Abstr.).

Cheeke, P.R., and L.R. Shull (1985). pp:393-477 in: Natural toxicants in feeds and poisonous plants. AVI Publishing, Westport, CT.

Clement, B. A., and T.D. Phillips (1985). Advances in the detection and determination of mycotoxins via capillary GC/quadrupole mass spectrometry. Toxicologist 5(1):232.(Abstr.)

Cotty, P. J., P. Bayman, D. S. Egel, and K. S. Elias (1994). Agriculture, aflatoxins and Aspergillus, p. 1-27. In K. A. Powell, A. Renwick, and J. F. Peberdy (ed.), The genus Aspergillus: from taxonomy and genetics to industrial applications. Plenum Press, New York, N.Y.

Cullen, D. ; E.B. Smalley, and R,W. Caldwell (1982). New process for T-2 toxin production. Appl. Environ. Microbiol.44:371- 375.

Dale, N. and R.D. Wyatt (1995). Impact of a Sodium bentonite and an aluminosilicate on protecting chicks from aflatoxicosis. Poultry Sci. (Abstr.)184: 62-62. 
Davidson, J.N., J.G Babish, K.A. Delaney, D.R. Taylor, and T.D. Philips (1987). Hydrated sodium calcium aluminosilicate decreases the bioavailability of aflatoxins in the chicken. Poultry Sci. 66(Suppl. 1):89.(Abstr.)

Doerr, J.A. ; P.B. Hamilton, and H.R. Burmeister (1981). T-2 toxicosis and blood coagulation in young chickens. Toxicol. Appl. Pharmacol. 60: 157162.

Duncan, D.B. (1955). Multiple range and F; test. Biometric 11:42.

Edrington, T.S. ; L.F. Kubena, R.B. Harvey, and G.E. Rottinghaus (1997). Influence of a superactivated charcoal on the toxic effects of aflatoxins or T-2 toxin in growing broilers. Poultry Sci.76: 1205-1211.

Mesopotamia J. of Agric.

(4) 2005

(ISSN $1815-316 \mathrm{X})$

Vol.(33) No.

Hoerr, F.J. ; W.W. Carltonm B. Yagen, and A.Z. Joffe (1982). Mycotoxicosis caused by either T-2 toxin or diacetoxyscirpenol in the diet of broiler chickens. Fundam. Appl. Toxicol. 2: 121-124.

Huff, W.E. ; L.E. Kubena, R.B. Harvey, D.E. Corre, and H.H. Mollenhaure (1986). Progression of aflatoxicosis in broiler chickens. Poultry Sci. 65 : 1891-1899.

Huff, W.E. ; R.B. Harvey, and L.E. Kubena (1988). Toxic synergism between aflatoxin and T-2 toxin in broiler chickens. Poultry Sci. 67 : 1418-1423.

Kubena, L. F., R.B. Harvey, W.E.Huff, D.E. Corrier, T.D. Phillips, and G.E. Rottinghaus (1990). Efficacy of a hydrated sodium calcium aluminosilicate to reduce the toxicity of aflatoxins and T-2 toxin. Poultry Sci. 69:1078-1086.

Kubena, L. F., E.E. Smith, A. Gentles, R.B. Harvey, T.S. Edrington, T.D. Phillips, and G.E. Rottinghaus (1994). Individual and combined toxicity of T-2 toxin and cyclopiazonic acid in broiler chicks. Poultry Sci. 73:1390-1397.

Kubena, L. F., T.S. Edrington, C. Kamps-Holtzapple,. R.B. Harvey, M.H. Elissalde, and G.E. Rottinghaus (1995a). Influence of fuminosin B1 present in Fusarium moniliforme culture materials and T-2 toxin in turkey poults. Poultry Sci. 74:306-313.

Kubena, L. F., T.S. Edrington, C. Kamps-Holtzapple,. R.B. Harvey, M.H. Elissalde, and G.E. Rottinghaus (1995b). Effects of feeding fuminosin B1 present in Fusarium moniliforme culture materials and aflatoxins singly and in combination to turkey poults. Poultry Sci. 74:1295-1303.

Kubena, L. F., R.B. Harvey, R.H. Bailey, S.A. Buckley, and G.E. Rottinghaus (1998). Effects of hydrated sodium calcium aluminosilicate (T-Bind ${ }^{\mathrm{TM}}$ ) on mycotoxicosis in young broiler chickens. Poultry Sci. 77:1502-1509.

Jain, N.C. (1986). Schalm's Veterinary heamatology. 4 th ed., Lea and Febiger, Philadelphia, pp:35-36.

Ibrahim, I.K. ; K.M.T. Al-Jubory (2000). Ameliorative effects of sodium bentonite on phagocytosis and Newcastle disease antibody formation in broiler chickens during aflatoxicosis. Res. Vet. Sci. 69: 119-122.

Lawrence, J.F. and P.M Scott,. (1993). Determination of mycotoxins and phycotoxins. In: Barceló, D., ed., Environmental Analysis: Techniques, Applications and Quality Assurance, Amsterdam: Elsevier, pp. 273-309.

Nabney, J. and B.F. Nesbitt (1965). A spectrophotometric method of determining the aflatoxin . Analyst . 90: 155-160 . 
Natt, M. P. and C.A. Herrick (1952). A new blood diluent for counting erythrocytes and leucocytes of the chicken. Poultry Sci. 31:735-738.

Phillips, T.D., L.F. Kubena, R.B. Harvey, D.S. Taylor, and N.D. Heidelbaugh (1988). Hydrated sodium calcium aluminosilicate: a high affinity sorbent for aflatoxins. Poultry Sci. 67:243-247.

SAS Version, Statistical Analysis System (2001) . SAS Institute Inc., Cary , NC. 27512 - 8000 , USA.

Sunderman, F.W., R. MacFate, D.A. McFayden, G.F. Stevenson and B.C. Copeland (1953). Symposium clinical haemoglobinometry. Am. J. Clin. Path. 23:519-598.

West, S. ; R.D. Wyatt and P.B. Hamilton (1973) .Increases yield of aflatoxin by incremental increases of temperature. Appl. Microbiol. Y Y:1 • \^-1019.

Wiseman, H.G. ; W.C. Tacobson and W.E. Harmeyer (1967) . Note on removal of pigments from chloroform extracts of aflatoxin cultures with copper carbonate . J.Assoc. of Agric. Chem. 50: 982-983.

Wyatt, R.D. , W.M. Colwell, P.B. Hamilton, and H.R. Burmeister (1973). Neural disturbances in chickens caused by dietary T-2 toxin . Appl. Microbiol. 26:757761. 